\title{
FAKTOR-FAKTOR YANG MEMPENGARUHI PARTISIPASI ANGGOTA KOPERASI DAN KESEJAHTERAAN ANGGOTA PADA KOPERASI UNIT DESA (KUD) DI KABUPATEN JEMBRANA
}

\author{
I Ketut Catur ${ }^{1}$ \\ Nyoman Djinar Setiawina ${ }^{2}$ \\ email: iketutcatur57@gmail.com \\ ${ }^{1,2}$ Fakultas Ekonomi dan Bisnis Universitas Udayana (Unud), Bali, Indonesia
}

\begin{abstract}
ABSTRAK
Penelitian ini bertujuan untuk menganalisis pengaruh pengetahuan perkoperasian, kemampuan pengurus, pelayanan koperasi, minat berkoperasi dan partisipasi anggota koperasi pada KUD terhadap kesejahteraan anggota di Kabupaten Jembrana, dianalisis dengan partial least square (PLS). Lokasi penelitian dilakukan di Kabupaten Jembrana. Jenis data yang digunakan dalam penelitian ini kuantitatif dan kualitatif. Sumber data yang digunakan dalam penelitian ini adalah data primer dari hasil kuisioner kepada responden. Hasil analisis menunjukkan bahwa pengetahuan perkoperasian, kemampuan pengurus, kualitas pelayanan koperasi dan minat berkoperasi pada KUD berpengaruh positif dan signifikan partisipasi anggota KUD di Kabupaten Jembrana. Pengetahuan perkoperasian, kemampuan pengurus, dan pelayanan koperasi berpengaruh tidak signifikan terhadap kesejahteraan anggota, sedangkan minat berkoperasi dan partisipasi anggota koperasi pada KUD berpengaruh positif dan signifikan terhadap kesejahteraan anggota di Kabupaten Jembrana. Partisipasi anggota koperasi pada KUD memediasi secara signifikan pengaruh kemampuan pengurus, pelayanan koperasi dan minat berkoperasi terhadap kesejahteraan anggota, namun pengaruh pengetahuan perkoperasian terhadap kesejahteraan anggota dimediasi tidak signifikan oleh partisipasi anggota koperasi pada KUD di Kabupaten Jembrana.

Kata Kunci : Koperasi Unit Desa (KUD), pengetahuan perkoperasian, kemampuan pengurus, kualitas pelayanan, minat berkoperasi, partisipasi anggota, kesejahteraan anggota.
\end{abstract}

\begin{abstract}
This research aims to analyze the influence of cooperate knowledge, the ability of administrators, service cooperatives, cooperate interest and participation of the members of the cooperative in the cooperate against the welfare of society in Jembrana Regency, analyzed with partial least square (PLS). The location of the research done in Jembrana Regency. Types of data used in this research is quantitative and qualitative. The source of the data used in this research is the primary data from the results of the questionnaire to respondents. The results of the analysis showed that $\mathrm{n}$ knowledge, the ability of administrators, service quality of cooperation and interest in cooperate on the positive and significant participation of influential members of the village Jembrana Regency. Cooperate knowledge, the ability of the Executive Board, and the Ministry of cooperatives was not significant effect against the welfare of society, while the interest and participation of the members of the cooperative in the village of positive and significant effect against community welfare in Jembrana Regency. The participation of members of the cooperative in the village mediated significantly influences the ability of the Executive Board, the Ministry of cooperation and interest in cooperate against the welfare of the community, but the influence of perkoperasian knowledge against the welfare of society mediated by the insignificant participation of members of the cooperative in the village Jembrana Regency.
\end{abstract}

Keywords: cooperative, knowledge, ability, quality of service, care taker of the interest berkoperasi, member participation, the welfare of the community. 


\section{PENDAHULUAN}

Harapan terciptanya efisiensi ekonomi yang didasari efisiensi sosial merupakan sifat positif koperasi. Koperasi Unit Desa dibentuk sebagai wadah penggerak peranan dan tanggung jawab petani dalam rangka mengembangkan diversifikasi usahanya (Nasution, 2002). Pemberdayaan KUD perlu diarahkan kepada perwujudan KUD yang mandiri dan berdaya saing di antara pelaku ekonomi lainnya.

Berdasarkan latar belakang di atas adapun tujuan penelitian ini adalah untuk menganalisis pengaruh pengetahuan perkoperasian, kemampuan pengurus, kualitas pelayanan koperasi dan minat berkoperasi pada KUD terhadap partisipasi anggota KUD, menganalisis pengaruh pengetahuan perkoperasian, kemampuan pengurus, pelayanan koperasi, minat berkoperasi dan partisipasi anggota koperasi pada KUD terhadap kesejahteraan anggota, menganalisis apakah partisipasi anggota koperasi pada KUD memediasi pengaruh pengetahuan perkoperasian, kemampuan pengurus, pelayanan koperasi dan minat berkoperasi terhadap kesejahteraan anggota di Kabupaten Jembrana.

\section{METODE PENELITIAN}

\section{Lokasi Penelitian}

Penelitian dilakukan pada KUD di Kabupaten Jembrana, dengan pertimbangan bahwa KUD merupakan bentuk koperasi yang paling lambat perkembangannya di Kabupaten Jembrana. Ditandai dengan jumlahnya yang paling sedikit, apalagi sejak tahun 2014 jumlahnya tidak mengalami perubahan.

\section{Definisi Operasional Variabel}

1) Pengetahuan perkoperasian $\left(X_{1}\right)$ adalah segala sesuatu yang diketahui berkenaan dengan kehidupan perkoperasian yang sesuai dengan Undang-Undang perkoperasian. Pengetahuan perkoperasian terdiri dari indikator pengetahuan tentangtujuan koperasi, fungsi dan peran koperasi, hak dan kewajiban anggota koperasi, prinsip koperasi, serta perangkat organisasi koperasi. Alat pengukuran yang digunakan adalah dengan skala likert. 
2) Kemampuan pengurus $\left(X_{2}\right)$ adalah sifat yang melekat pada diri pengurus yang memungkinkan pengurus melaksanakan suatu tindakan mental atau fisik untuk memimpin organisasi dan usaha koperasi yang dikelola. Kemampuan pengurus terdiri dari indikator kemampuan pengurus dalam menghasilkan ide, kemampuan pengurus dalam melaksanakan administrasi, kemampuan pengurus dalam melaksanakan tugas-tugas, kemampuan teknis dan penetapan tujuan prestasi. Diukur dengan skala likert.

3) Kualitas pelayanan $\left(X_{3}\right)$ adalah usaha koperasi dalam memberikan pelayanan yang sebaik mungkin terhadap apa yang diperlukan anggota, sehingga anggota memperoleh kemudahan dalam memperoleh barang atau jasa yang digunakan untuk memenuhi kebutuhan. Kualitas pelayanan terdiri dari indikator keandalan, daya tanggap, jaminan, empati, dan keberwujudan fisik hasil pelayanan. Diukur dengan skala likert.

4) Minat berkoperasi $\left(\mathrm{X}_{4}\right)$ adalah keinginan yang tinggi yang diwujudkan dalam perasaan senang, perhatian, konsentrasi, sadar, dan mempunyai kemauan terlibat dalam kegiatan koperasi. Minat berkoperasi terdiri dari indikator perasaan senang berkoperasi, perhatian pada koperasi, konsentrasi pada kegiatan koperasi, kesadaran berkoperasi, kemauan dalam kegiatan berkoperasi, dan keterlibatan dalam kegiatan berkoperasi.Diukur dengan skala likert.

5) Partisipasi anggota koperasi ( $\left.Y_{1}\right)$ adalah keikutsertaan seseorang atau sekelompok orang dalam aktivitas koperasi, baik permodalan, pemanfaatan jasa di KUD dan menghadiri rapat anggota sehingga tercapai tujuan bersama yakni memperoleh kesejahteraan. Partisipasi anggota koperasi terdiri dari indikator partisipasi anggota dalam Rapat Anggota Tahunan (RAT), partisipasi anggota dalam permodalan, dan partisipasi anggota dalam menggunakan jasa koperasi. Diukur dengan skala likert.

6) Kesejahteraan anggota $\left(\mathrm{Y}_{2}\right)$ adalah tingkat kemakmuran anggota koperasi. Terdiri dari indikator tingkat pendapatan, tingkat kesehatan. Diukur dengan skala likert. 


\section{Teknik Analisis Data}

Dalam penelitian ini metode analisis yang digunakan adalah analisis PLS. Analisis ini digunakan untuk mengetahui pengaruh variabel bebas terhadap varibel terikat. Analisis persamaan struktural SEM (Structural Equation Modelling) yang berbasis komponen dengan menggunakan Partial Least Squares (PLS) dipilih sebagai alat analisis.

Dalam PLS terdapat dua macam komponen pada model kausal yaitu: model pengukuran (measurement model) dan model struktural (structural model). Model pengukuran berupa indikator-indikator yang dapat diobservasi. Sedang model struktural berupa konstruk-konstruk laten yang tidak dapat diobservasi. Analisis PLS menspesifikasikan hubungan antara variabel antara lain: outer model, inner model dan pengaruh tidak langsung sebagai berikut :

1) Outer model

Outer model merupakan spesifikasi hubungan antara variabel laten dengan indikatornya, juga sering disebut sebagai measurement model atau model pengukuran.

Selanjutnya evaluasi model pengukuran atau outer model dilakukan dengan beberapa cara yaitu :

a) Convergent validity dari model pengukuran dengan refleksif indikator dinilai berdasarkan korelasi antara item score/component score dengan construct score yang dihitung dengan PLS. Nilai yang ditoleransi minimal 0,50 dianggap cukup (Chin, 1998 dalam Ghozali,2011).

b) Discriminant validity dari model pengukuran dengan indikator refleksif, dinilai berdasarkan cross loading pengukuran dengan konstruk. Jika korelasi konstruk dengan item pengukuran lebih besar daripada ukuran konstruk lainnya, maka menunjukkan bahwa konstruk laten memprediksi ukuran pada blok mereka lebih baik, daripada ukuran pada blok lainnya. Fornell dan Larcker dalam Ghozali (2008) merekomendasikan nilai $A V E$ harus lebih besar 0.50. Formula untuk menghitung AVE adalah sebagai berikut : 
$\mathrm{AVE}=$

$$
\Sigma \lambda \mathrm{i}^{2}+\Sigma \mathrm{I} \operatorname{var}(\varepsilon \mathrm{i})
$$

Keterangan :

$\lambda \mathrm{i}=$ component loading ke indikator

$\operatorname{var}(\varepsilon \mathrm{i})=1-\lambda \mathrm{i}^{2}$

c) Composite reliability blok indikator yang mengukur suatu konstruk dapat dievaluasi dengan dua macam ukuran yaitu internal consistency dan cronbach's alpha. Dengan menggunakan output yang dihasilkan oleh PLS. Chin dalam Ghozali (2008) menyatakan suatu variabel laten memiliki reliabilitas yang tinggi apabila nilai composite reliability dan atau cronbach's alpha di atas 0,70 . Formula untuk menghitungnya adalah sebagai berikut :

$$
(\Sigma \lambda \mathrm{i})^{2}
$$

$\rho c=$

$$
(\Sigma \lambda \mathrm{i})^{2}+\Sigma \mathrm{i} \operatorname{var}(\varepsilon \mathrm{i})
$$

Keterangan :

$\lambda \mathrm{i}=$ component loading ke indikator

$\operatorname{var}(\varepsilon \mathrm{i})=1-\lambda \mathrm{i}^{2}$

\section{2) Inner model}

Untuk meyakinkan bahwa pengukuran-pengukuran konstruk valid dan reliabel adalah dengan menilai inner model atau structural model. Model persamaan dalam penelitian ini, adalah :

(a) $X_{2}=\beta_{1} X_{1}+\varepsilon_{1}$

(b) $X_{3}=\beta_{2} X_{1}+\varepsilon_{2}$

(a) $Y_{1}=\beta_{3} X_{1}+\beta_{4} X_{2}+\varepsilon_{3}$

(b) $Y_{2}=\beta_{6} X_{1}+\beta_{7} X_{2}+\beta_{8} X_{3}+\beta_{9} Y_{1}+\varepsilon_{2}$

Dimana :

$\mathrm{Y}_{1}=$ Partisipasi Anggota koperasi

$\mathrm{Y}_{2}=$ Kesejahteraan anggota

$\mathrm{X}_{1}=$ Pengetahuan perkoperasian

$\mathrm{X}_{2}=$ Kemampuan pengurus 
$\mathrm{X}_{3}=$ Pelayanan Koperasi

$\mathrm{X}_{4}=$ Minat berkoperasi

$\beta 1,, \beta 9=$ koefisien jalur

$\varepsilon 1, \ldots \varepsilon 4=$ inner residual

3) Uji peran variabel mediasi

Untuk mengetahui adanya peran variabel mediasi atas pengaruh varibel independen terhadap variabel dependen pada model persamaan struktural (SEM) seperti dalam PLS digunakan dengan hasil output Partial Least Square (PLS Inderect Effects.

\section{Evaluasi Outer Model}

\section{1) Uji Validitas}

Cara untuk menguji validitas konstruk (construct validity) adalah bila terdapat korelasi yang kuat antara konstruk dan item-item pertanyaannya dan hubungan yang lemah dengan variabel lainnya. Validitas konstruk sendiri terdiri dari validitas konvergen dan validitas diskriminan.

1) Validitas Konvergen (Convergent Validity)

Validitas konvergen dari model pengukuran yang memiliki indikator reflektif dapat dinilai berdasarkan loading factor (yaitu korelasi antara item score/component score dengan construct score) indikator-indikator yang mengukur konstruk tersebut. Suatuindikator dapat dikatakan valid jika mempunyai loading factor di atas 0,5 terhadap konstruk yang dituju. Tabel 1 berikut menunjukkan nilai loading factor masing-masing indikator terhadap konstruknya. 
Tabel 1

Hasil Uji Validitas Konvergen

\begin{tabular}{|c|c|c|c|c|c|c|}
\hline \multirow[b]{2}{*}{$\begin{array}{l}\text { Indi- } \\
\text { kator }\end{array}$} & \multicolumn{6}{|c|}{ Variabel Laten } \\
\hline & $\begin{array}{l}\text { Pengetahuan } \\
\text { Perkoperasian } \\
\quad\left(\mathrm{X}_{1}\right)\end{array}$ & $\begin{array}{l}\text { Kemampuan } \\
\text { Pengurus } \\
\left(\mathrm{X}_{2}\right)\end{array}$ & $\begin{array}{l}\text { Pelayanan } \\
\text { Koperasi } \\
\left(\mathrm{X}_{3}\right)\end{array}$ & $\begin{array}{l}\text { Minat } \\
\text { Berkoperasi } \\
\quad\left(\mathrm{X}_{4}\right)\end{array}$ & $\begin{array}{l}\text { Partisipasi } \\
\text { Anggota } \\
\text { Koperasi } \\
\left(\mathrm{Y}_{1}\right)\end{array}$ & $\begin{array}{c}\text { Kesejahteraan } \\
\text { anggota }\left(\mathrm{Y}_{2}\right)\end{array}$ \\
\hline $\mathrm{X}_{11}$ & 0.873 & & & & & \\
\hline $\mathrm{X}_{12}$ & 0.795 & & & & & \\
\hline $\mathrm{X}_{13}$ & 0.759 & & & & & \\
\hline $\mathrm{X}_{14}$ & 0.850 & & & & & \\
\hline $\mathrm{X}_{21}$ & & 0.839 & & & & \\
\hline $\mathrm{X}_{22}$ & & 0.893 & & & & \\
\hline $\mathrm{X}_{23}$ & & 0.896 & & & & \\
\hline $\mathrm{X}_{31}$ & & & 0.739 & & & \\
\hline $\mathrm{X}_{32}$ & & & 0.700 & & & \\
\hline $\mathrm{X}_{33}$ & & & 0.864 & & & \\
\hline $\mathrm{X}_{34}$ & & & 0.874 & & & \\
\hline $\mathrm{X}_{35}$ & & & 0.692 & & & \\
\hline $\mathrm{X}_{41}$ & & & & 0.727 & & \\
\hline $\mathrm{X}_{42}$ & & & & 0.808 & & \\
\hline $\mathrm{X}_{43}$ & & & & 0.861 & & \\
\hline $\mathrm{X}_{44}$ & & & & 0.852 & & \\
\hline $\mathrm{X}_{45}$ & & & & 0.825 & & \\
\hline $\mathrm{X}_{46}$ & & & & 0.833 & & \\
\hline $\mathrm{Y}_{11}$ & & & & & 0.796 & \\
\hline $\mathrm{Y}_{12}$ & & & & & 0.860 & \\
\hline $\mathrm{Y}_{13}$ & & & & & 0.905 & \\
\hline $\mathrm{Y}_{21}$ & & & & & & 0.917 \\
\hline $\mathrm{Y}_{22}$ & & & & & & 0.904 \\
\hline AVE & 0.673 & 0.768 & 0.605 & 0.671 & 0.731 & 0.829 \\
\hline \multicolumn{7}{|c|}{$\begin{array}{l}\text { Sumber: Lampiran } \\
\text { Berdasarkan Tabel } 1 \text { terlihat bahwa seluruh loading factor indikator } \\
\text { memiliki nilai lebih besar dari 0,6. Hal ini menunjukkan bahwa syarat validitas }\end{array}$} \\
\hline \multicolumn{7}{|c|}{ 2) Uji Validitas Diskriminan (Discriminant Validity) } \\
\hline \multicolumn{7}{|c|}{$\begin{array}{l}\text { Pengukuran discriminant validity dari model pengukuran dapat dinilai } \\
\text { arkan cross loading indikator pengukuran dengan konstruknya. Tabel } 2 \\
\text { jikan perbandingan antara korelasi indikator suatu konstruk dengan korelasi }\end{array}$} \\
\hline
\end{tabular}


nilai lebih tinggi dibandingkan dengan korelasi indikator tersebut dengan konstruk lain, maka dikatakan konstruk memiliki discriminant validity yang tinggi. Tabel 2 menunjukkan cross loading antara indikator dengan masing-masing variabel laten.

Tabel 2

Hasil Cross Loading Antara Indikator Dengan Variabel

\begin{tabular}{|c|c|c|c|c|c|c|}
\hline \multirow[b]{2}{*}{$\begin{array}{l}\text { Indi- } \\
\text { kator }\end{array}$} & \multicolumn{6}{|c|}{ Variabel Laten } \\
\hline & $\begin{array}{l}\text { Pengetahuan } \\
\text { Perkoperasian } \\
\left(\mathrm{X}_{1}\right)\end{array}$ & $\begin{array}{c}\text { Kemampuan } \\
\text { Pengurus } \\
\left(\mathrm{X}_{2}\right)\end{array}$ & $\begin{array}{c}\text { Pelayanan } \\
\text { Koperasi } \\
\left(\mathrm{X}_{3}\right)\end{array}$ & $\begin{array}{c}\text { Minat } \\
\text { Berkoperasi } \\
\left(\mathrm{X}_{4}\right)\end{array}$ & $\begin{array}{l}\text { Partisipasi } \\
\text { Anggota } \\
\text { Koperasi } \\
\left(\mathrm{Y}_{1}\right)\end{array}$ & $\begin{array}{l}\text { Kesejahteraan } \\
\text { Anggota }\left(\mathrm{Y}_{2}\right)\end{array}$ \\
\hline $\mathrm{X}_{11}$ & 0.873 & 0.564 & 0.372 & 0.425 & 0.520 & 0.500 \\
\hline $\mathrm{X}_{12}$ & 0.795 & 0.444 & 0.270 & 0.367 & 0.422 & 0.314 \\
\hline$X_{13}$ & 0.759 & 0.486 & 0.460 & 0.415 & 0.452 & 0.451 \\
\hline $\mathrm{X}_{14}$ & 0.850 & 0.580 & 0.472 & 0.523 & 0.552 & 0.374 \\
\hline$X_{21}$ & 0.507 & 0.839 & 0.515 & 0.486 & 0.524 & 0.416 \\
\hline $\mathrm{X}_{22}$ & 0.609 & 0.893 & 0.554 & 0.538 & 0.642 & 0.544 \\
\hline $\mathrm{X}_{23}$ & 0.552 & 0.896 & 0.630 & 0.541 & 0.605 & 0.546 \\
\hline$X_{31}$ & 0.363 & 0.463 & 0.739 & 0.485 & 0.439 & 0.337 \\
\hline$X_{32}$ & 0.498 & 0.646 & 0.700 & 0.572 & 0.660 & 0.538 \\
\hline $\mathrm{X}_{33}$ & 0.372 & 0.558 & 0.864 & 0.590 & 0.611 & 0.474 \\
\hline $\mathrm{X}_{34}$ & 0.359 & 0.472 & 0.874 & 0.602 & 0.589 & 0.503 \\
\hline$X_{35}$ & 0.257 & 0.324 & 0.692 & 0.494 & 0.465 & 0.443 \\
\hline$X_{41}$ & 0.450 & 0.537 & 0.531 & 0.727 & 0.646 & 0.529 \\
\hline $\mathrm{X}_{42}$ & 0.506 & 0.623 & 0.576 & 0.808 & 0.710 & 0.610 \\
\hline $\mathrm{X}_{43}$ & 0.423 & 0.479 & 0.559 & 0.861 & 0.678 & 0.611 \\
\hline$X_{44}$ & 0.512 & 0.520 & 0.671 & 0.852 & 0.701 & 0.575 \\
\hline$X_{45}$ & 0.330 & 0.351 & 0.531 & 0.825 & 0.653 & 0.517 \\
\hline $\mathrm{X}_{46}$ & 0.379 & 0.414 & 0.630 & 0.833 & 0.675 & 0.650 \\
\hline$Y_{11}$ & 0.392 & 0.460 & 0.579 & 0.660 & 0.796 & 0.539 \\
\hline $\mathrm{Y}_{12}$ & 0.589 & 0.605 & 0.571 & 0.674 & 0.860 & 0.677 \\
\hline$Y_{13}$ & 0.536 & 0.656 & 0.708 & 0.785 & 0.905 & 0.687 \\
\hline$Y_{21}$ & 0.432 & 0.541 & 0.559 & 0.659 & 0.715 & 0.917 \\
\hline$Y_{22}$ & 0.493 & 0.511 & 0.640 & 0.640 & 0.642 & 0.904 \\
\hline
\end{tabular}

Sumber: Lampiran

Berdasarkan Tabel 2 dapat diketahui bahwa discrimanant validity sudah terpenuhi dengan melihat crossloading sudah terpenuhi dengan bagus karena indikatornya memiliki crossloading lebih pada konstruknya dibandingkan terhadap konstruk lainnya. Sebagai contoh konstruk pengetahuan perkoperasian (X1) memiliki crossloading minimal 0,759, sedangkan pada konstruk lainnya indikatornya memiliki crossloading lebih kecil dari nilai itu, yaitu paling besar sebesar 0,580. Metode lain untuk melihat discrimanant validity adalah dengan melihat square root of average variance extracted (RSAVE) setiap konstruk 
dengan korelasi antara konstruk dengan konstruk lainnya seperti yang disajikan pada Tabel 3 .

Tabel 3 dapat disimpulkan konstruk pengetahuan perkoperasian, kemampuan pengurus, pelayanan koperasi, minat berkoperasi, partisipasi anggota koperasi, dan kesejahteraan masyarakat di Kabupaten Jembrana juga valid. Hal ini dapat dilihat nilai akar kuadrat dari AVE yang dicetak dengan huruf tebal, lebih besar dari korelasi antar kontruk, yaitu angka-angka yang ada di sebelahnya. Misalnya nilai square roots atas AVE konstruk pengetahuan perkoperasian $\left(\mathrm{X}_{1}\right)$ dengan korelasi terhadap konstruk pengetahuan perkoperasian $\left(\mathrm{X}_{1}\right)$ adalah 0,820 , dimana nilai tersebut lebih besar dari nilai varians dengan konstruk lain, yaitu: dengan konstruk kemampuan pengurus $\left(\mathrm{X}_{2}\right)$ senilai 0,637 ; dengan konstruk pelayanan koperasi $\left(\mathrm{X}_{3}\right)$ senilai 0,485 ; dengan konstruk minat berkoperasi $\left(\mathrm{X}_{4}\right)$ senilai 0,530; dengan konstruk partisipasi anggota koperasi $\left(\mathrm{Y}_{1}\right)$ senilai 0,597 ; dan dengan konstruk kesejahteraan masyarakat $\left(\mathrm{Y}_{2}\right)$ senilai 0,507 .

Tabel 3

Root Square Average Variance Extracted (RSAVE) dan Korelasi Antar Konstruk

\begin{tabular}{lcccccc}
\hline \multicolumn{1}{c}{$\begin{array}{c}\text { Variabel } \\
\text { Laten }\end{array}$} & $\begin{array}{c}\text { Pengetahuan } \\
\text { Perkoperasian } \\
(\mathrm{X} 1)\end{array}$ & $\begin{array}{c}\text { Kemam- } \\
\text { puan } \\
\text { Pengurus } \\
(\mathrm{X} 2)\end{array}$ & $\begin{array}{c}\text { Pelayanan } \\
\text { Koperasi } \\
(\mathrm{X} 3)\end{array}$ & $\begin{array}{c}\text { Minat } \\
\text { Berkope- } \\
\text { rasi (X4) }\end{array}$ & $\begin{array}{c}\text { Partisipasi } \\
\text { Anggota } \\
\text { Koperasi } \\
\text { (Y1) }\end{array}$ & $\begin{array}{c}\text { Kesejah- } \\
\text { teraan } \\
\text { anggota } \\
\text { (Y2) }\end{array}$ \\
\hline $\begin{array}{l}\text { Pengetahuan } \\
\begin{array}{l}\text { Perkoperasian } \\
\text { (X1) }\end{array}\end{array}$ & $\mathbf{0 . 8 2 0}$ & & & & \\
$\begin{array}{l}\text { Kemampuan } \\
\text { Pengurus (X2) }\end{array}$ & 0.637 & $\mathbf{0 . 8 7 6}$ & & & \\
$\begin{array}{l}\text { Pelayanan } \\
\text { Koperasi (X3) } \\
\text { Minat }\end{array}$ & 0.485 & 0.648 & $\mathbf{0 . 7 7 8}$ & & \\
$\begin{array}{l}\text { Berkoperasi } \\
\text { (X4) }\end{array}$ & 0.530 & 0.597 & 0.714 & $\mathbf{0 . 8 1 9}$ & & \\
$\begin{array}{l}\text { Partisipasi } \\
\text { Anggota }\end{array}$ & 0.597 & 0.678 & 0.727 & 0.828 & $\mathbf{0 . 8 5 5}$ & \\
$\begin{array}{l}\text { Koperasi (Y1) } \\
\text { Kesejahteraan } \\
\begin{array}{l}\text { Masyarakat } \\
\text { (Y2) }\end{array}\end{array}$ & 0.507 & 0.578 & 0.603 & 0.713 & 0.746 & $\mathbf{0 . 9 1 1}$ \\
\hline
\end{tabular}

Sumber: Lampiran

\section{Pengujian Hipotesis}


Dalam tahap pengujian hipotesis, sangat penting untuk memperhatikan adanya pengaruh yang ditunjukkan oleh arah anak panah antarvariabel, yaitu partisipasi anggota koperasi dapat dijelaskan oleh variabel pengetahuan perkoperasian, kemampuan pengurus, pelayanan koperasi, minat berkoperasi, partisipasi anggota koperasi, dan kesejahteraan masyarakat.

Sebagaimana telah dijelaskan sebelumnya bahwa dalam penelitian ini terdapat tiga hipotesis penelitian. Selanjutnya masing-masing hipotesis penelitian dijabarkan kembali pada masing-masing hipotesis statistik antar variabel penelitian.Secara ringkas, Tabel 5 berikut menjelaskan hasil pengujian hipotesis penelitian.

Tabel 5

Pengujian Hipotesis Penelitian

\begin{tabular}{|c|c|c|c|c|}
\hline Notasi & Koef. & T statistik & $\mathrm{P}$ value & Hasil \\
\hline $\mathrm{H} 1$ & & & & Hipotesis \\
\hline$(\mathrm{X} 1 \rightarrow \mathrm{Y} 1)$ & 0.120 & 1.701 & 0.045 & Diterima \\
\hline $\mathrm{H} 2$ & & & & Hipotesis \\
\hline$(\mathrm{X} 2 \rightarrow \mathrm{Y} 1)$ & 0.164 & 2.723 & 0.003 & Diterima \\
\hline $\mathrm{H} 3$ & & & & Hipotesis \\
\hline$(\mathrm{X} 3 \rightarrow \mathrm{Y} 1)$ & 0.177 & 2.128 & 0.017 & Diterima \\
\hline $\mathrm{H} 4$ & & & & Hipotesis \\
\hline$(\mathrm{X} 4 \rightarrow \mathrm{Y} 1)$ & 0.540 & 7.733 & 0.000 & Diterima \\
\hline $\mathrm{H} 5$ & & & & Hipotesis \\
\hline$(\mathrm{X} 1 \rightarrow \mathrm{Y} 2)$ & 0.046 & 0.494 & 0.311 & Ditolak \\
\hline H6 & & & & Hipotesis \\
\hline$(\mathrm{X} 2 \rightarrow \mathrm{Y} 2)$ & 0.087 & 0.998 & 0.159 & Ditolak \\
\hline $\mathrm{H} 7$ & & & & Hipotesis \\
\hline$(\mathrm{X} 3 \rightarrow \mathrm{Y} 2)$ & 0.029 & 0.260 & 0.398 & Ditolak \\
\hline $\mathrm{H} 8$ & & & & Hipotesis \\
\hline$(\mathrm{X} 4 \rightarrow \mathrm{Y} 2)$ & 0.278 & 1.835 & 0.034 & Diterima \\
\hline H9 & & & & Hipotesis \\
\hline$(\mathrm{Y} 1 \rightarrow \mathrm{Y} 2)$ & 0.409 & 3.007 & 0.001 & Diterima \\
\hline H1 - H9 & & & & Hipotesis \\
\hline $\mathrm{X} 1 \rightarrow \mathrm{Y} 1 \rightarrow \mathrm{Y} 2$ & & & & Ditolak \\
\hline a) $\mathrm{X} 1 \rightarrow \mathrm{Y} 1$ & 0.120 & 1.701 & 0.045 & \\
\hline b) $\mathrm{Y} 1 \rightarrow \mathrm{Y} 2$ & 0.409 & 3.007 & 0.001 & \\
\hline Indirect & 0.049 & 1.423 & 0.078 & \\
\hline $\mathrm{H} 2-\mathrm{H} 9$ & & & & Hipotesis \\
\hline $\mathrm{X} 2 \rightarrow \mathrm{Y} 1 \rightarrow \mathrm{Y} 2$ & & & & Diterima \\
\hline a) $\mathrm{X} 2 \rightarrow \mathrm{Y} 1$ & 0.164 & 2.723 & 0.003 & \\
\hline b) $\mathrm{Y} 1 \rightarrow \mathrm{Y} 2$ & 0.409 & 3.007 & 0.001 & \\
\hline Indirect & 0.067 & 2.062 & 0.020 & \\
\hline $\mathrm{H} 3-\mathrm{H} 9$ & & & & Hipotesis \\
\hline $\mathrm{X} 3 \rightarrow \mathrm{Y} 1 \rightarrow \mathrm{Y} 2$ & & & & Diterima \\
\hline c) $\mathrm{X} 3 \rightarrow \mathrm{Y} 1$ & 0.177 & 2.128 & 0.017 & \\
\hline d) $\mathrm{Y} 1 \rightarrow \mathrm{Y} 2$ & 0.409 & 3.007 & 0.001 & \\
\hline Indirect & 0.072 & 1.692 & 0.046 & \\
\hline
\end{tabular}


$\mathrm{X} 4 \rightarrow \mathrm{Y} 1 \rightarrow \mathrm{Y} 2$

\begin{tabular}{|c|c|c|}
\hline $\mathrm{X} 4 \rightarrow \mathrm{Y} 1$ & 0.540 & 7.733 \\
\hline d) $\mathrm{Y} 1 \rightarrow \mathrm{Y} 2$ & 0.409 & 3.007 \\
\hline Indirect & 0.221 & 2.704 \\
\hline
\end{tabular}

Sumber: Lampiran

Berdasarkan Tabel 5 dapat dijelaskan bahwa terdapat sejumlah hipotesis yang diterima maupun ditolak, karena nilai p-value atau signifikansinya lebih besar dari 0,05 .

\section{Pengujian Model Struktural}

Model struktural dalam PLS perlu dievaluasi dengan menggunakan $R$ square untuk variabel dependen dan nilai signifikansinya berdasarkan nilai $t$-values pada setiap path. Adapun model struktural penelitian ini dapat dilihat pada Gambar 1.

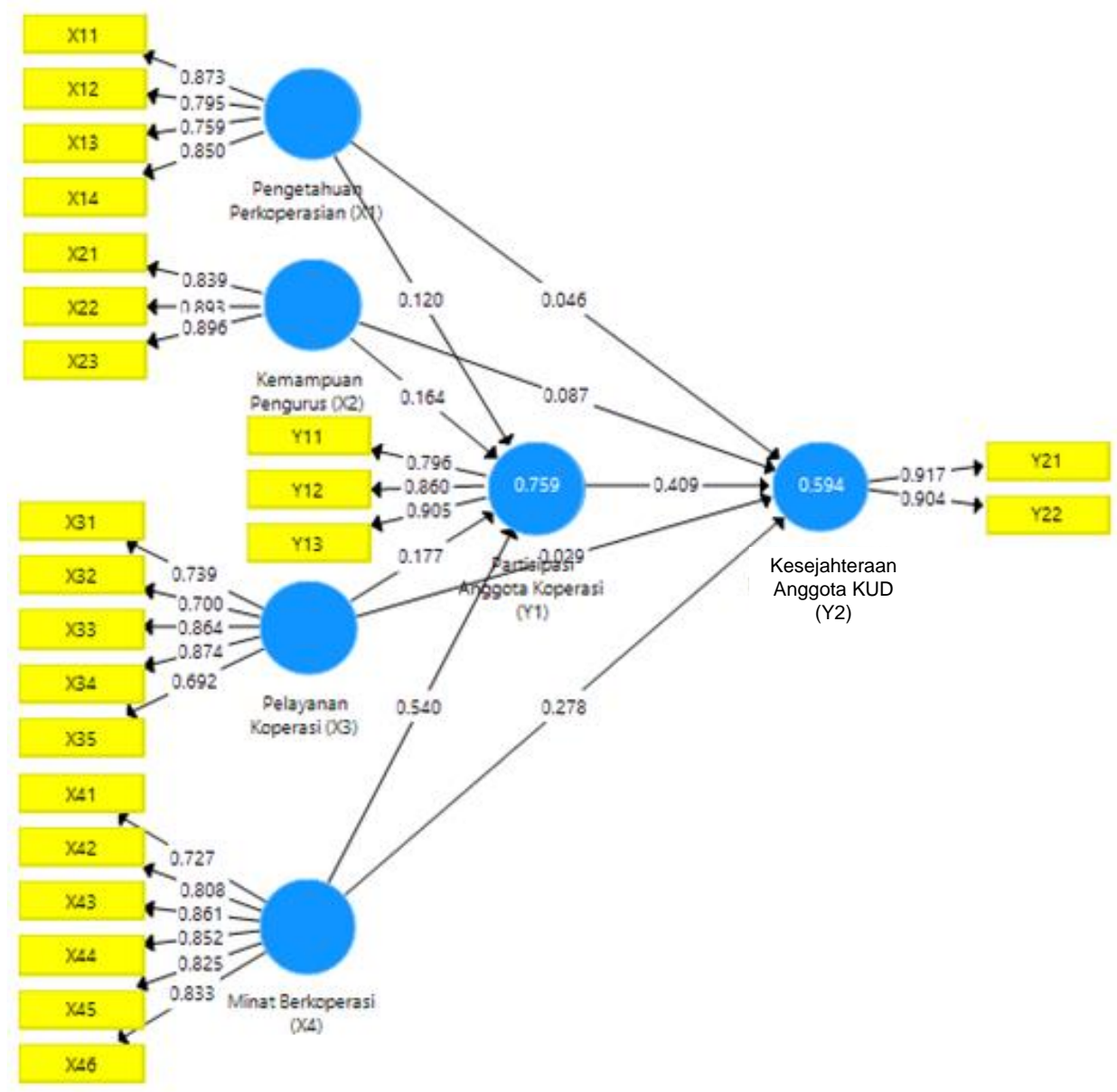

Gambar 1

Kerangka Model Penelitian Dengan Path Coefficient 
Setelah model yang diestimasi memenuhi kriteria outer model, berikutnya dilakukan pengujian inner model. Menilai inner model sama artinya dengan melihat hubungan antar variabel laten dengan melihat hasil estimasi path coefficient dan tingkat signifikannya. Tabel 6 menunjukkan nilai $R$-square untuk setiap variabel endogen.

Tabel 6

Nilai $R$-square

\begin{tabular}{lc}
\hline \multicolumn{1}{c}{ Variabel } & R Square \\
\hline Partisipasi Anggota Koperasi (Y1) & 0.759 \\
Kesejahteraan Anggota (Y2) & 0.594 \\
Sumber: Lampiran &
\end{tabular}

Tabel 6 menunjukkan nilai $R$-square 0,759 untuk variabel partisipasi anggota koperasi. Artinya bahwa variabilitas partisipasi anggota koperasi dapat dijelaskan oleh variabel pengetahuan perkoperasian, kemampuan pengurus, pelayanan koperasi, dan minat berkoperasi sebesar 75,9 persen. Selanjutnya variabel kesejahteraan anggota dapat dijelaskan oleh variabel partisipasi anggota koperasi dapat dijelaskan oleh variabel pengetahuan perkoperasian, kemampuan pengurus, pelayanan koperasi, minat berkoperasi, dan partisipasi anggota koperasi sebesar 59,4 persen.

Berdasarkan $\mathrm{R}^{2}$ pada Tabel 6, maka dapat dihitung $\mathrm{Q}^{2}$ atau Stone Geiser $Q$ Square test, yaitu:

$$
\begin{aligned}
\mathrm{Q}^{2} & =1-\{(1-0,759)(1-0,594)\} \\
& =1-\{(0,241)(0,406)\} \\
& =0,902
\end{aligned}
$$

Hasil perhitungan $\mathrm{Q}^{2}$ sebesar 0,902 sehingga dapat dikatakan memiliki predictive prevelance yang kuat, sehingga model yang dihasilkan layak digunakan untuk memprediksi. Angka sebesar 0,902 dapat diartikan bahwa variasi kesejahteraan masyarakat sebesar 90,2 persen mampu dijelaskan oleh variasi variabel partisipasi anggota koperasi dapat dijelaskan oleh variabel pengetahuan perkoperasian, kemampuan pengurus, pelayanan koperasi, minat berkoperasi, dan partisipasi anggota koperasi, sedangkan sisanya 9,2 persen dijelaskan oleh variabel lain di luar model. 


\section{Pengaruh Langsung, Pengaruh Tidak Langsung, dan Pengaruh Total Antar Variabel}

Analisis pengaruh langsung, pengaruh tidak langsung, maupun pengaruh total, dapat menjelaskan hubungan antarvariabel penelitian (variabel laten). Untuk mengetahui pengaruh langsung antar variabel dapat dilihat dari hasil analisis nilai path coefficients yang ditampilkan pada Tabel 7.

Tabel 7

Path Coefficient

\begin{tabular}{|c|c|c|c|c|c|}
\hline & $\begin{array}{l}\text { Original } \\
\text { Sample } \\
\text { (O) }\end{array}$ & $\begin{array}{c}\text { Sample } \\
\text { Mean } \\
\text { (M) }\end{array}$ & $\begin{array}{l}\text { Standard } \\
\text { Deviation } \\
\text { (STDEV) }\end{array}$ & $\begin{array}{l}\text { T Statistics } \\
(|\mathrm{O} / \mathrm{STERR}|)\end{array}$ & $\begin{array}{c}\mathrm{P} \\
\text { Values }\end{array}$ \\
\hline $\begin{array}{l}\text { Pengetahuan Perkoperasian (X1) } \rightarrow \\
\text { Partisipasi Anggota Koperasi (Y1) }\end{array}$ & 0.120 & 0.118 & 0.070 & 1.701 & 0.045 \\
\hline $\begin{array}{l}\text { Pengetahuan Perkoperasian (X1) } \rightarrow \\
\text { Kesejahteraan Anggota (Y2) }\end{array}$ & 0.046 & 0.048 & 0.093 & 0.494 & 0.311 \\
\hline $\begin{array}{l}\text { Kemampuan Pengurus (X2) } \rightarrow \\
\text { Partisipasi Anggota Koperasi (Y1) }\end{array}$ & 0.164 & 0.165 & 0.060 & 2.723 & 0.003 \\
\hline $\begin{array}{l}\text { Kemampuan Pengurus (X2) } \rightarrow \\
\text { Kesejahteraan Anggota (Y2) }\end{array}$ & 0.087 & 0.079 & 0.088 & 0.998 & 0.159 \\
\hline $\begin{array}{l}\text { Pelayanan Koperasi (X3) } \rightarrow \text { Partisipasi } \\
\text { Anggota Koperasi (Y1) }\end{array}$ & 0.177 & 0.177 & 0.083 & 2.128 & 0.017 \\
\hline $\begin{array}{l}\text { Pelayanan Koperasi (X3) } \rightarrow \\
\text { Kesejahteraan Anggota (Y2) }\end{array}$ & 0.029 & 0.025 & 0.110 & 0.260 & 0.398 \\
\hline $\begin{array}{l}\text { Minat Berkoperasi (X4) } \rightarrow \text { Partisipasi } \\
\text { Anggota Koperasi (Y1) }\end{array}$ & 0.540 & 0.539 & 0.070 & 7.733 & 0.000 \\
\hline $\begin{array}{l}\text { Minat Berkoperasi (X4) } \rightarrow \\
\text { Kesejahteraan Anggota (Y2) }\end{array}$ & 0.278 & 0.274 & 0.152 & 1.835 & 0.034 \\
\hline $\begin{array}{l}\text { Partisipasi Anggota Koperasi (Y1) } \rightarrow \\
\text { Kesejahteraan Anggota (Y2) }\end{array}$ & 0.409 & 0.418 & 0.136 & 3.007 & 0.001 \\
\hline
\end{tabular}

Sumber: Lampiran

Berdasarkan Tabel 7 dapat dijelaskan bahwa pada pengaruh antar variabel penelitian adalah seluruhnya bersifat positif, namun tidak semuanya signifikan. Pengaruh variabel pengetahuan perkoperasian $\left(\mathrm{X}_{1}\right)$, kemampuan pengurus $\left(\mathrm{X}_{2}\right)$, dan pelayanan koperasi $\left(\mathrm{X}_{3}\right)$ terhadap kesejahteraan masyarakat $\left(\mathrm{Y}_{2}\right)$ bersifat tidak signifikan.

Untuk mengetahui pengaruh tidak langsung antar variabel dapat dilihat dari hasil analisis nilai indirect effects yang ditampilkan pada Tabel 8. 
Tabel 8

Nilai Indirect Effects

\begin{tabular}{|c|c|c|c|c|c|c|}
\hline \multicolumn{3}{|c|}{ Konstruk } & \multirow{2}{*}{$\begin{array}{c}\begin{array}{c}\text { Original } \\
\text { Sample }\end{array} \\
0.049\end{array}$} & \multirow{2}{*}{$\begin{array}{c}\text { T Statistics } \\
1.423\end{array}$} & \multirow{2}{*}{$\begin{array}{c}\text { P Values } \\
0.078\end{array}$} & \multirow{2}{*}{$\begin{array}{c}\text { Ket. } \\
\text { Mediasi } \\
\text { Penuh }\end{array}$} \\
\hline $\begin{array}{l}\text { Pengetahuan } \\
\text { Perkoperasian } \\
\text { (X1) }\end{array}$ & $\rightarrow$ & $\begin{array}{l}\text { Kesejahteraan } \\
\text { Anggota (Y2) }\end{array}$ & & & & \\
\hline $\begin{array}{l}\text { Kemampuan } \\
\text { Pengurus (X2) }\end{array}$ & $\rightarrow$ & $\begin{array}{l}\text { Kesejahteraan } \\
\text { Anggota (Y2) }\end{array}$ & 0.067 & 2.062 & 0.020 & $\begin{array}{c}\text { Mediasi } \\
\text { Penuh }\end{array}$ \\
\hline $\begin{array}{l}\text { Pelayanan } \\
\text { Koperasi (X3) }\end{array}$ & $\rightarrow$ & $\begin{array}{l}\text { Kesejahteraan } \\
\text { Anggota (Y2) }\end{array}$ & 0.072 & 1.692 & 0.046 & $\begin{array}{c}\text { Mediasi } \\
\text { Penuh }\end{array}$ \\
\hline $\begin{array}{l}\text { Minat } \\
\text { Berkoperasi } \\
\text { (X4) }\end{array}$ & $\rightarrow$ & $\begin{array}{l}\text { Kesejahteraan } \\
\text { Anggota (Y2) }\end{array}$ & 0.221 & 2.704 & 0.004 & $\begin{array}{c}\text { Mediasi } \\
\text { Parsial }\end{array}$ \\
\hline
\end{tabular}

Sumber: Lampiran 8

Berdasarkan Tabel 8 diketahui bahwa secara tidak langsung pengaruh pengetahuan perkoperasian, kemampuan pengurus, dan pelayanan koperasi melalui partisipasi anggota koperasi bersifat mediasi penuh, dengan mengingat bahwa secara langsung variabel-variabel tersebut berpengaruh tidak signifikan terhadap kesejahteraan anggota. Sedangkan mengingat bahwa pengaruh minat berkoperasi secara langsung mapun tidak langsung melalui partisipasi anggota koperasi terhadap kesejahteraan masyarakat bersifat signifikan, maka hubungannya disebut mediasi parsial.

Berdasarkan Tabel 7 dan Tabel 8 dapat dihitung pengaruh langsung, pengaruh tidak langsung dan pengaruh total antarvariabel dalam penelitian ini, sebagaimana dirangkum dan disajikan pada Tabel 9.

Tabel 9

Ringkasan Pengaruh Langsung, Pengaruh Tidak Langsung, dan Pengaruh Total Antarvariabel Laten

\begin{tabular}{|c|c|c|c|c|c|c|}
\hline \multirow{3}{*}{ Variabel Independen } & \multicolumn{6}{|c|}{ Variabel Dependen } \\
\hline & \multicolumn{3}{|c|}{$\begin{array}{l}\text { Partisipasi Anggota } \\
\text { Koperasi (Y1) }\end{array}$} & \multicolumn{3}{|c|}{$\begin{array}{c}\text { Kesejahteraan Masyarakat } \\
\text { (Y2) }\end{array}$} \\
\hline & $\mathrm{PL}$ & PTL & PT & PL & PTL & PT \\
\hline $\begin{array}{l}\text { Pengetahuan Perkoperasian } \\
\text { (X1) }\end{array}$ & 0.120 & - & 0.120 & $0.046^{*}$ & $0.049 *$ & $0.095^{*}$ \\
\hline Kemampuan Pengurus (X2) & 0.164 & - & 0.164 & $0.087^{*}$ & 0.067 & 0.155 \\
\hline Pelayanan Koperasi (X3) & 0.177 & - & 0.177 & $0.029 *$ & 0.072 & $0.101 *$ \\
\hline Minat Berkoperasi (X4) & 0.540 & - & 0.540 & 0.278 & 0.221 & 0.499 \\
\hline $\begin{array}{l}\text { Partisipasi Anggota Koperasi } \\
\text { (Y1) }\end{array}$ & - & - & - & 0.409 & - & 0.409 \\
\hline
\end{tabular}

Keterangan :PL adalah pengaruh langsung PTL adalah pengaruh tidak langsung PT adalah pengaruh total *) Non Sig. 


\section{Pembahasan}

Pengaruh Pengetahuan Perkoperasian Terhadap Partisipasi Anggota Koperasi pada KUD di Kabupaten Jembrana

Hasil penelitian menunjukkan bahwa secara langsung pengetahuan perkoperasian berpengaruh positif dan signifikan terhadap partisipasi anggota pada KUD di Kabupaten Jembrana. Artinya, apabila pengetahuan perkoperasian meningkat, maka partisipasi anggota koperasi juga akan meningkat. Anggota koperasi akan berpartisipasi aktif apabila anggota tersebut mempunyai pengetahuan perkoperasian. Hal ini senada dengan pendapat Anoraga (2003) bahwa untuk mengusahakan anggota agar berpartisipasi aktif harus mengetahui apa yang menjadi tujuan koperasi, bilamana usaha dimulai dan selesai, apa kegiatan yang akan dilaksanakan serta apa hak yang bisa dilaksanakan oleh anggota koperasi.

\section{Pengaruh Kemampuan Pengurus Terhadap Partisipasi Anggota Koperasi pada KUD di Kabupaten Jembrana}

Kemampuan pengurus koperasi juga terbukti secara langsung berpengaruh positif dan signifikan terhadap partisipasi anggota pada KUD di Kabupaten Jembrana. Hal ini menunjukkan bahwa bila kemampuan pengurus koperasi meningkat akan diikuti juga oleh peningkatan partisipasi anggota koperasi, demikian sebaliknya. Pengurus koperasi harus mempunyai kemampuan dalam memimpin koperasi.. Pengurus yang baik diharapkan bisa menumbuhkan dan meningkatkan partisipasi dari para anggotanya, bagaimanapun maju mundurnya sebuah koperasi pada prinsipnya banyak bergantung pada aktivitas pengurusnya, tidak ada koperasi yang dapat dikatakan maju atau berhasil tanpa kerja optimal yang dilaksanakan pengurus dan manajernya (Edilius dan Sudarsono, 2005).

\section{Pengaruh Pelayanan Koperasi Terhadap Partisipasi Anggota Koperasi pada KUD di Kabupaten Jembrana}

Selanjutnya terlihat juga bahwa pelayanan koperasi juga berpengaruh positif dan signifikan terhadap partisipasi anggota koperasi pada KUD di 
Kabupaten Jembrana. Semakin baik pelayanan koperasi yang diberikan, maka partisipasi anggota koperasi juga akan mengalami peningkatan. Adanya persaingan dengan sesama koperasi atau badan usaha lainnya menuntut koperasi untuk meningkatkan pelayanannya kepada anggota (Kusnadi, 2005).

\section{Pengaruh Minat Berkoperasi Terhadap Partisipasi Anggota Koperasi pada KUD di Kabupaten Jembrana}

Terkait dengan minat berkoperasi, ternyata juga berpengaruh positif dan signifikan secara langsung terhadap partisipasi anggota koperasi pada KUD di Kabupaten Jembrana. Minat berkoperasi yang tinggi akan meningkatkan partisipasi anggota koperasi. Apabila anggota sudah mengetahui manfaat menjadi anggota koperasi maka akan tumbuh motivasi untuk berpartisipasi aktif dalam kegiatan koperasi. Hani Handoko (2000) menyimpulkan "motivasi yaitu keadaan dalam pribadi seseorang yang mendorong keinginan individu untuk melakukan kegiatankegiatan tertentu guna mencapai tujuan”. Menurut G.R. Terry (dalam Wirasasmita, 1990) menjelaskan "motivasi adalah keinginan yang terdapat pada diri individu yang merangsangnya untuk melakukan tindakan-tindakan". Jadi motivasi dapat dikatakan sebagai dorongan bagi diri seseorang untuk melakukan perubahan tingkah laku yang lebih baik dalam memenuhi kebutuhannya.

\section{Pengaruh Pengetahuan Perkoperasian Terhadap Kesejahteraan Anggota KUD di Kabupaten Jembrana}

Hasil penelitian menunjukkan bahwa secara langsung pengetahuan perkoperasian berpengaruh tidak signifikan terhadap kesejahteraan anggota KUD di Kabupaten Jembrana. Artinya, apabila peruabahan pengetahuan perkoperasian tidak terlalu signifikan mempengaruhi partisipasi anggota koperasi. Upaya untuk peningkatan kesejahteraan memang tidak secara langsung merupakan dampak dari pengetahuan perkoperasian, kemampuan pengurus, maupun pelayanan perkoperasian, apabila anggota koperasi tidak secara aktif ikut berpartisipasi. Dengan aktif berpartisipasi pada koperasi maka akan dapat meningkatkan 
pendapatan koperasi serta anggota memperoleh manfaat sehingga baru kesejahteraan meningkat.

\section{Pengaruh Kemampuan Pengurus Terhadap Kesejahteraan Anggota KUD di Kabupaten Jembrana}

Demikian halnya kemampuan pengurus koperasi juga secara langsung berpengaruh tidak signifikan terhadap kesejahteraan anggota KUD di Kabupaten Jembrana. Hal ini menunjukkan bahwa bila kemampuan pengurus koperasi meningkat ataupun menurun tidak diikuti oleh perubahan kesejahteraan anggota secara signifikan.

\section{Pengaruh Pelayanan Koperasi Terhadap Kesejahteraan Anggota KUD di Kabupaten Jembrana}

Selanjutnya terlihat juga bahwa pelayanan koperasi juga berpengaruh tidak signifikan terhadap kesejahteraan anggota KUD di Kabupaten Jembrana. Semakin baik ataupun buruk pelayanan koperasi yang diberikan, maka kesejahteraan anggota tidak akan berubah secara signifikan.

Pengaruh Minat Berkoperasi Terhadap Kesejahteraan Anggota KUD di Kabupaten Jembrana

Terkait dengan minat berkoperasi, ternyata berpengaruh positif dan signifikan secara langsung terhadap kesejahteraan anggota di Kabupaten Jembrana. Minat berkoperasi yang tinggi akan meningkatkan kesejahteraan anggota. Demikian halnya dengan partisipasi anggota koperasi juga berpengaruh positif dan signifikan terhadap kesejahteraan anggota di Kabupaten Jembrana.

Pengaruh Partisipasi Anggota Terhadap Kesejahteraan Anggota KUD di Kabupaten Jembrana

Semakin tinggi partisipasi anggota pada KUD maka akan dapat meningkatkan kesejahteraan anggota. Minat mempunyai pengaruh yang besar 
dalam kehidupan manusia, begitu pula dalam kehidupan berkoperasi. Sebagai konsekuensi dari keanggotaan yang bersifat sukarela dan terbuka untuk semua warga negara. Banyak anggota koperasi yang hanya sekedar ikut-ikutan atau karena kurang mengerti ingin mencari keuntungan pribadi dan alasan-alasan yang berdasarkan kesadaran yang dituntut sebagai anggota koperasi (Widiyanti, 2002).

\section{Peran Partisipasi Anggota Koperasi pada KUD Dalam Memediasi Pengaruh Pengetahuan PerkoperasianTerhadap Kesejahteraan Anggota KUD}

Secara tidak langsung, ternyata partisipasi anggota koperasi memediasi secara tidak signifikan pengaruh pengetahuan perkoperasian terhadap kesejahteraan masyarakat. Artinya efek antara pengetahuan perkoperasian bila dilakukan dengan partisipasi anggota koperasi ternyata tidak berdampak signifikan terhadap kesejahteraan anggota KUD.

\section{Peran Partisipasi Anggota Koperasi pada KUD Dalam Memediasi Pengaruh Kemampuan Pengurus Terhadap Kesejahteraan Anggota KUD}

Hasil penelitian menunjukkan bahwa secara tidak langsung partisipasi anggota koperasi memediasi secara signifikan pengaruh kemampuan pengurus pada KUD terhadap kesejahteraan anggota KUD di Kabupaten Jembrana. Kemampuan pengurus sangat penting peranannya dalam menjalankan koperasi. Begitu juga dengan kualitas pelayanan koperasi kepada anggota, kualitas pelayanan haruslah baik untuk mencapai kepuasan pelanggan. Selain itu, anggota koperasi juga harus berpartisipasi aktif dalam koperasi. Dengan

\section{Peran Partisipasi Anggota Koperasi pada KUD Dalam Memediasi Pengaruh Pelayanan Koperasi Terhadap Kesejahteraan Anggota KUD}

Hasil penelitian menunjukkan bahwa secara tidak langsung partisipasi anggota koperasi memediasi secara signifikan pengaruh pelayanan koperasi pada KUD terhadap kesejahteraan anggota KUD di Kabupaten Jembrana. Pada prinsipnya koperasi harus memperhatikan dan mendasarkan pada bagaimana 
anggota mau berpartisipasi di dalam koperasi, agar anggota mau berpartisipasi di dalam koperasi, maka ia harus mendapatkan manfaat dari koperasi, karena partisipasi anggota ditentukan oleh sejauh mana koperasi dapat memberikan manfaat yang mungkin tidak didapatkan dari lembaga bukan koperasi. Koperasi dapat meningkatkan partisipasi anggotanya dengan memberikan pelayanan yang terbaik bagi para anggotanya. Oleh karena itu diperlukan suatu konsep berwawasan pelanggan dimana koperasi memusatkan perhatian penuh terhadap kepuasan pelanggan..

Hal ini juga diperkuat dengan oleh Bapak Merta direktur KUD Amerta Buana, dalam wawancara pada tanggal 22 Desember 2017 bahwa:

"Partisipasi anggota pada koperasi kami, masih memanfaatkan jasa usaha koperasi dilakukan dengan anggota menjadi pelanggan setia koperasi yaitu dengan berbelanja atau bertransaksi dengan usaha koperasi. Anggota disini selalu membeli produk yang dijual di koperasi misalnya tabung gas, air minum/galon. Hasil wawancara dengan 3 anggota koperasi dia mengatakan bahwa dia selalu memanfaatkan jasa usaha koperasi contonya jasa usaha cuci mobil dan motor, usaha toko, dan usaha fotocopy."

\section{Peran Partisipasi Anggota Koperasi pada KUD Dalam Memediasi Pengaruh Minat Berkoperasi Terhadap Kesejahteraan Anggota KUD}

Hasil penelitian menunjukkan bahwa secara tidak langsung partisipasi anggota koperasi memediasi secara signifikan pengaruh minat berkoperasi KUD terhadap kesejahteraan anggota KUD di Kabupaten Jembrana.

\section{Simpulan}

Berdasarkan analisis data dan pembahasan dapat disimpulkan beberapa hal sebagai berikut.

1) Pengetahuan perkoperasian berpengaruh positif dan signifikan terhadap partisipasi anggota KUD di Kabupaten Jembrana.

2) Kemampuan pengurus berpengaruh positif dan signifikan terhadap partisipasi anggota KUD di Kabupaten Jembrana.

3) Kualitas pelayanan koperasi berpengaruh positif dan signifikan terhadap partisipasi anggota KUD di Kabupaten Jembrana. 
4) Minat berkoperasi berpengaruh positif dan signifikan terhadap partisipasi anggota KUD di Kabupaten Jembrana.

5) Pengetahuan perkoperasian berpengaruh positif dan tidak signifikan terhadap kesejahteraan anggota KUD di Kabupaten Jembrana

6) Kemampuan pengurus berpengaruh positif dan tidak signifikan terhadap kesejahteraan anggota KUD di Kabupaten Jembrana

7) Pelayanan koperasi berpengaruh tidak signifikan terhadap kesejahteraan anggota KUDdi Kabupaten Jembrana.

8) Minat berkoperasi berpengaruh positif dan signifikan terhadap kesejahteraan anggota KUD di Kabupaten Jembrana.

9) Partisipasi anggota koperasi pada KUD berpengaruh positif dan signifikan terhadap kesejahteraan anggota KUD di Kabupaten Jembrana.

10) Partisipasi anggota koperasi pada KUD memediasi secara tidak signifikan pengaruh pengetahuan perkoperasian terhadap kesejahteraan anggota KUD di Kabupaten Jembrana.

11) Partisipasi anggota koperasi pada KUD memediasi secara signifikan pengaruh kemampuan pengurus terhadap kesejahteraan anggota KUD di Kabupaten Jembrana.

12) Partisipasi anggota koperasi pada KUD memediasi secara signifikan pengaruh pelayanan koperasi terhadap kesejahteraan anggota KUD di Kabupaten Jembrana.

13) Partisipasi anggota koperasi pada KUD memediasi secara signifikan pengaruh minat berkoperasi terhadap kesejahteraan anggota KUD di Kabupaten Jembrana.

\section{Saran}

Berdasarkan hasil analisis dan kesimpulan yang diperoleh, saran-saran yang diajukan adalah:

1) Penelitian ini baru menganalisis faktor internal yang mempengaruhi kesejahteraan anggota KUD. Selanjutnya perlu diteliti juga mengenai faktor eksternal yang berpengaruh terhadap kesejahteraan anggota KUD. 
2) Mengingat bahwa KUD merupakan koperasi yang berperan penting bagi petani dan bidang agribisnis, maka pemerintah perlu memberikan pembinaan yang sifatnya teknis bagi pengurus atau pengelola KUD.

3) Pemerintah kiranya dapat melakukan monitoring dan evaluasi keliling yang sifatnya membantu KUD yang mengalami permasalahan atau memerlukan pembinaan.

4) Mengingat bahwa masyarakat di Kabupaten Jembrana banyak yang masih bergelut di bidang pertanian, maka pengurus koperasi hendaknya lebih inovatif dan lebih aktif dalam merekrut anggota baru, serta meningkatkan partisipasi anggota yang telah ada sebelumnya. Upaya yang dapat dilakukan adalah menyelenggarakan berbagai kegiatan yang dapat merangsang minat anggota koperasi.

5) Koperasi perlu meningkatkan pengetahuan anggota tentang koperasi dengan menyelenggarakan pelatihan tentang perkoperasian, koperasi perlu membuat suatu inisiatif yang baru dalam usaha penjualannya, misalnya dengan memberikan kupon berhadiah pada anggota yang membeli barang di koperasi untuk meningkatkan minat anggota berkoperasi. 


\section{DAFTAR PUSTAKA}

Amirullah, Rindyah Hanafi. 2002. Pengantar Manajemen. Yogyakarta: Graha Ilmu.

Anoraga, Pandji Sudantoko. 2002. Koperasi, Kewirausahaan, dan Usaha Kecil. Jakarta: Rineka Cipta. Cipta. dan Ninik Widiyanti. 2003. Dinamika Koperasi. Jakarta: Rineka

Arikunto, Suharsimi. 2002.Prosedur Penelitian Suatu Pendekatan Praktek. Jakarta: Rineka Cipta.

Ambruster, P. 2001, Cooperative banks in Europe: Values and practices to promote development. IRU Courier (3), pp. 10-13.

Andy, 2010.Koperasi Indonesia.Http://edukasi.kompasiana.com/2010/07/29/ koperasi-indo/. Diakses 10 Agustus 201202.00 WIB

Anwar, Khairil. 2011. Pendapatan Masyarakat. http://khairilanwarsemsi.blogspot.com/2011/12/pendapatanmasyarakat.html. Daikses 1 Februari 2013 07.00 WIB

Antara, M dan Komenaung. 2010. Kinerja Koperasi Unit Desa di Provinsi Bali : Pendekatan Structural Equation Model. http://www.docstoc.com. Diakses : 12 April 2017

Baswir, Revrisond. 2000. Koperasi Indonesia. Yogyakarta: BPEP Yogyakarta.

BurhanuddinR. 2006. Evaluasi Program Bantuan Dana Bergulir Melalui KSP/USP Koperasi (Pola PKPS-BBM, Agribisnis dan Syariah). Jurnal Pengkajian Koperasidan UKM Nomor 1 Tahun I - 2006.

Biro Pusat Statistik.2011.Kabupaten Jembrana dalam Angka 2011.BPS :Jembrana.

Biro Pusat Statistik.2013.Kabupaten Jembrana dalam Angka 2011.BPS : Jembrana.

Bunga Rosavinda. 2013. Peran Koperasi Unit Desa (KUD) terhadap Peningkatan Pendapatan Anggota (Studi Kasus KUD”Sri Among Tani” Kecamatan Plosoklaten Kabupaten Kediri).Jurnal. 2013

Chronographer, Ekhardhi. 2010. Pendapatan, Biaya, dan Usaha Kecil. http://ekhardhi.blogspot.com/2010/12/pendapatan-biaya-usaha-kecil.html. Daikses 1 Februari 2013 07.30 WIB 
Darwin Bangun. 1989. Manajemen Perusahaan. Jakarta: FKIP Universitas Lampung.

Darmawanto. 2015. Pengukuran Jatidiri dan Daya Saing Koperasi dengan Pendekatan Development Ladder Assesment (DLA) Studi pada KUD Subur, KPRI Universitas Brawijaya dan KWSU BAM di Kota Malang. Jurnal. 2015

Edilius dan Sudarsono. 2005. Koperasi Teori dan Praktek. Jakarta: Rineka Cipta.

Erfita. 2008. Pengaruh Pengetahuan Perkoerasian dan Minat Berkoperasi Terhadap Partisipasi Anggota KPRI Sejahtera, Kecamatan Jumartono, Kabupaten Karanganyar Tahun 2007. Skripsi. Semarang: Fakultas Ekonomi UNNES.

Fajar, Laksana. 2008.Manajemen Pemasaran. Yogyakarta: Graha Ilmu.

Federal Ministry of Agriculture and Rural Development (FMARD, 2002), Cooperative Policy for Nigeria, Abuja, Government Printer.

Ghozali, Imam. 2001. Aplikasi Analisis Multivariate dengan Program SPSS. Semarang: Badan Penerbit Universitas Diponegoro.

Galamedia.2012. Koperasi Kurang Diperhatikan.http://www.klikgalamedia.com/koperasi-kurang-diperhatikan. Diakses 10 Agustus 2012 $03.00 \mathrm{WIB}$

Hendrojogi. 2000.Koperasi, Asas-asas Teori, dan Praktik. Edisi 3. Jakarta: PT Raja Grafindo Persada.

Herlina. 2010. Pengaruh Kewirakoperasian Pengurus, Kualitas Pelayanan, Lingkungan Usaha Terhadap Partisipasi KPRI Guyub Rukun Kabupaten Banjarnegara. Skripsi. Semarang: UNNES.

Hoskinson et al. 2001. Manajemen Strategis. Jakarta: Salemba Empat.

Hanel, Alfred, 2005. Basic Aspect of Cooperative Organization and Policies for TheirPromotion in Developing Countries.Bandung : Universitas Padjadjaran dan MarbugUniversity

Hendrojogi, 2002.Koperasi Azas-Azas, Teori dan Praktek.Jakarta : PT RajaGrafindo Persada.

Indrawan, Rully. 2012. Dasar-dasar Koperasi: Implementasi dalam Manajemen. Http://rully-indrawan.tripod.com/rully03.htm . Diakses 13 November 2012 $05.00 \mathrm{WIB}$

Jasfar, Farida. 2005. Manajemen Jasa. Bogor: Ghalia Indonesia.

Jogiyanto. 2007. Sistem Informasi Keperilakuan. Yogyakarta: ANDI. 
Journal Of international 2005. Leadership and Organization Studies, Kedlington. Des.Vol 27.ISS.8 Pg.1199.

Journal Of international 2006. Transformational and Transactional Leadership : Association With Attitudes Toward Evidence-Based Practice, Kedlington. Des.Vol 27.ISS.8 Pg.1199

Journal Of international 2002. Does The Transactional-Transformastional Leadership Paradigm Transcend Organizational and National Boundaries, Bernard M.Bass State University of New York at Binghamton.

Kerllinger, Fred N. 2002.Asas-asas Penelitian Behavioral. Yogyakarta: Gajah Mada University Press.

Kusnadi, Hendar. 2005.Ekonomi Koperasi Untuk Perguruan Tinggi. Jakarta: Fakultas Ekonomi Universitas Indonesia.

Kartasapoetra G. 2005.Praktek Pengelolaan Koperasi.Jakarta : Rineka Cipta dan Bina Adiaksara 2001.Praktek Pengelolaan Koperasi. Jakarta: Rineka Cipta.

Nigerian Agricultural Cooperative And Rural Development Bank (NACRDB, 2004). Annual Report, Kaduna, NACRDB Headquarters.

Onyeagocha, S. 2008, Comparative study of the methods and performance of micro-finance institutions in southeastern Nigeria. Unpublished Ph.D thesis, Department of Agricultural Economics, University of Nigeria, Nsukka.

Pramudyani, Sinta. 2002. Skripsi Analisis Peran Koperasi Unit Desa (KUD) Dalam Peningkatan Pendapatan Anggota Peternak Sapi Perah.Bogor : Institut Pertanian Bogor.

Pengurus dan Pengawas KUD "Sri Among Tani”. 2011. Laporan Pertanggung Jawaban Pengurus dan Pengawas Ke XXXIX tahun 2011 (RAT). KUD Sri Among Tani : Plosoklaten

Pitaloka, Rieke Diah. 2012. UU Nomor 11 Tahun 2009, Tentang Kesejahteraan Sosial. http://www.riekediahpitaloka.com/legislasi/200901/uu-no-11tahun-2009-kesejahteraan-sosial/. diakses 27 Juli 2012.

Ropke, Jochen. 2002. Ekonomi Koperasi Teori dan Manajemen. Jakarta: Salemba Empat.

Rusdarti. 2009. Pengaruh Keterlibatan Pembina, Kemampuan Pengurus dan Partisipasi Anggota Terhadap Kinerja Keuangan Koperasi Pondok Pesantren. Jejak. Vol. 2, No. 1, Hal. 8 -21. UNNES. 
Roy, Ewell Paul, 1981. Cooperatives : Development, Principles and Management, The InterstatePrinters \& Publisher, Inc, Danville Illinois.

Ramdhani, Pratama Rus. 2010. Koperasi Dalam Pembangunan Sosial dan Ekonomi. Http://matakuliahekonomi.wordpress.com/tag/dampak-makrodari-organisi-koperasi/ diakses 13 November 2012 06.00 WIB

Rusdarti. 2009. Pengaruh Keterlibatan Pembina, Kemampuan pengurus, dan Partisipasi anggota terhadap kinerja Keuangan Koperasi Pondok Pesantren.Jejak, Volume 2 No 1 Hal 8-21: UNNES.

Sudiarditha, I Ketut R, dkk. 2013. Pengaruh Pengetahuan Anggota Tentang Koperasi dan Kualitas Pelayanan Terhadap Partisipasi Anggota Pada Koperasi Serba Usaha (KSU) Warga Sejahtera, Kelurahan Cipinang, Jakarta Timur. Jurnal Pendidikan Ekonomi dan Bisnis. Fakultas Ekonomi Universitas Negeri Jakarta. Jakarta.

Sukamdiyo,Ign. 1997. Manajemen Koperasi. Jakarta : Erlangga

Suyanto, 2007.Koperasi Unit Desa Mekar Ungaran dalam Meningkatkan Kesejahteraan Anggota dan Berbagai.Jurnal.Semarang: Universitas Negeri Semarang.

Slameto. 2003. Belajar dan Faktor-faktor yang Mempengaruhinya. Jakarta: Bumi Aksara.

Sudarsono dan Edilius. 2004. Koperasi Dalam Teori dan Praktek. Jakarta: PT Rineka Cipta.

Sugiyono. 2010.Metode Penelitian Kuantitatif, Kualitatif, dan $R \&$ D. Bandung: Alfabeta.

Suryana. 2006. Kewirausahaan. Jakarta: Salemba Empat.

Sucihati, Roos Nana. 2009. Materi Kuliah Pembangunan Pedesaan Bagian.Http://warnet69.blogspot.com/2009/05/materi-kuliahpembangunan-pedesaan.html diakses 27 Juli 2012

Sulistyo Purnomo, 2010. Pemberdayaan Koperasi Unit Desa Melalui Analisis Faktor-Faktor Kunci Manajemen. Jurnal Agrikultura. 2010

Tjiptono, Fandy. 2004. Total Quality Service (TQS). Yogyakarta: Andi Offset.

Tambunan, Togap dan Paruhuman Nasution. 2006.Pengkajian Peningkatan Daya Saing Usaha Kecil Menengah yang Berbasis Pengembangan Ekonomi Lokal.Jurnal Pengkajian Koperasi dan UKM Nomor 2 Tahun I- 2006.

Tamba. 2007. Koperasi Teori dan Praktik. Jakarta : Erlangga. 
I Ketut Catur, Nyoman Djinar Setiawina, Faktor-faktor yang mempengaruhi....................

Widiyanti, Ninik. 2007. Manajemen Koperasi. Jakarta: Rineka Cipta.

Winardi. 2004. Manajemen Perilaku Organisasi. Jakarta: Prenada Media. 